\title{
Problem of Excess Electricity and Capacity due to the Commissioning of the Astravets Nuclear Power Plant
}

\author{
B.I. Nigmatulin*, M.G. Saltanov
}

Institute of Energy Problems, Moscow, Russia

\begin{abstract}
The paper presents a review and analysis of sales and marketing opportunities for the electricity generated by the Astravets Nuclear Power Plant (NPP) in terms of sales destinations (domestic market, export to Europe and Russia). The study comprehensively scrutinizes the issues of competitiveness of the electricity generated by the Astravets NPP and parameters of its production cost, price, and repayment of investment. We address the economic, technological, and political risks of electricity sales, along with the standpoints of the leadership of the industry and those of academic and public organizations. A range of possible scenarios for the development of the situation is analyzed.
\end{abstract}

Index Terms: nuclear power plant, Astravets NPP, Russia, Belarus, electricity market, investment project, excess electricity.

\section{INTRODUCTION}

\section{Speaking of the Astravets Nuclear Power Plant}

The Astravets Nuclear Power Plant is the first nuclear power plant in Belarus, it is of the AES-2006 type. It comprises two VVER-1000 nuclear reactors. It is located at the northwestern border of Belarus in the agro-town of Vornyany, 18 kilometers from the town of Astravets in the Hrodna region, $40 \mathrm{~km}$ from the Lithuanian capital Vilnius.

The actual starting up of the first NPP reactor took place in August 2020. The official starting up of the first rector of the Astravets NPP took place on November 7, 2020. The main partner of Belarus in the NPP construction project is the Russian company Atomstroyexport.

\footnotetext{
* Corresponding author.

E-mail: maxisal@mail.ru
}

http://dx.doi.org/10.38028/esr.2020.04.0007

Received October 17, 2020. Revised November 09, 2020.

Accepted November 23, 2020. Available online February 01, 2021.

This is an open access article under a Creative Commons Attribution-NonCommercial 4.0 International License.

(C) 2020 ESI SB RAS and authors. All rights reserved.

\section{Speaking of money}

Under an agreement on cooperation in the construction of nuclear power plants, signed in 2011, Russia has committed to providing Belarus with a $\$ 10$ billion loan. The "ASE Group" is to become the general designer and contractor. The loan from Russia amounts to $90 \%$ of the NPP construction cost, while the remaining $10 \%$ is to be provided by Belarus. The loan repayment was to begin six months after the NPP commissioning and was to be made in equal installments every six months in USA dollars until 2035. Half of the used loan part was to be charged $5.23 \%$ per annum, and the other half was to be charged at a floating LIBOR rate (about $1 \%$ or less) $+1.83 \%$ per annum. Annual payments on this loan from 2021 to 2035 were estimated at $\$ 1$ billion. In 2020 , the governments of Belarus and Russia signed a protocol on amendments to the agreement on state export loan for the NPP construction by the Belorussian side, dated November 25, 2011. [1] The protocol provides for a two-year extension, compared to the current conditions, of the loan availability period, grace period, and, accordingly, the loan term. Under this document, the loan interest rate decreases to $3.3 \%$ per annum and changes from floating to fixed.

\section{Speaking of sales}

When deciding to build the Astravets NPP, the authorities estimated the demand for electricity in Belarus by 2020 at $47 \mathrm{kWh}$ [2]. There were plans to commission the first reactor of Astravets NPP in 2019 and the second one - in 2020. Now, the deadline has been pushed back by at least one year.

By this time, Belarus had failed to increase its economic potential to ensure demand for additional energy after the NPP commissioning.

In 2019, the electricity output of the existing plants was 39.755 billion $\mathrm{kWh}$. Two reactors of the Astravets NPP will generate $\sim 18$ billion $\mathrm{kWh}$ of electricity.

The question naturally arises: what to do with the "extra" electricity after the nuclear power plant is launched?

This issue is currently the most important for the two power systems of the two countries. There is a great deal of discussion, myths, and speeches on the subject. All the 


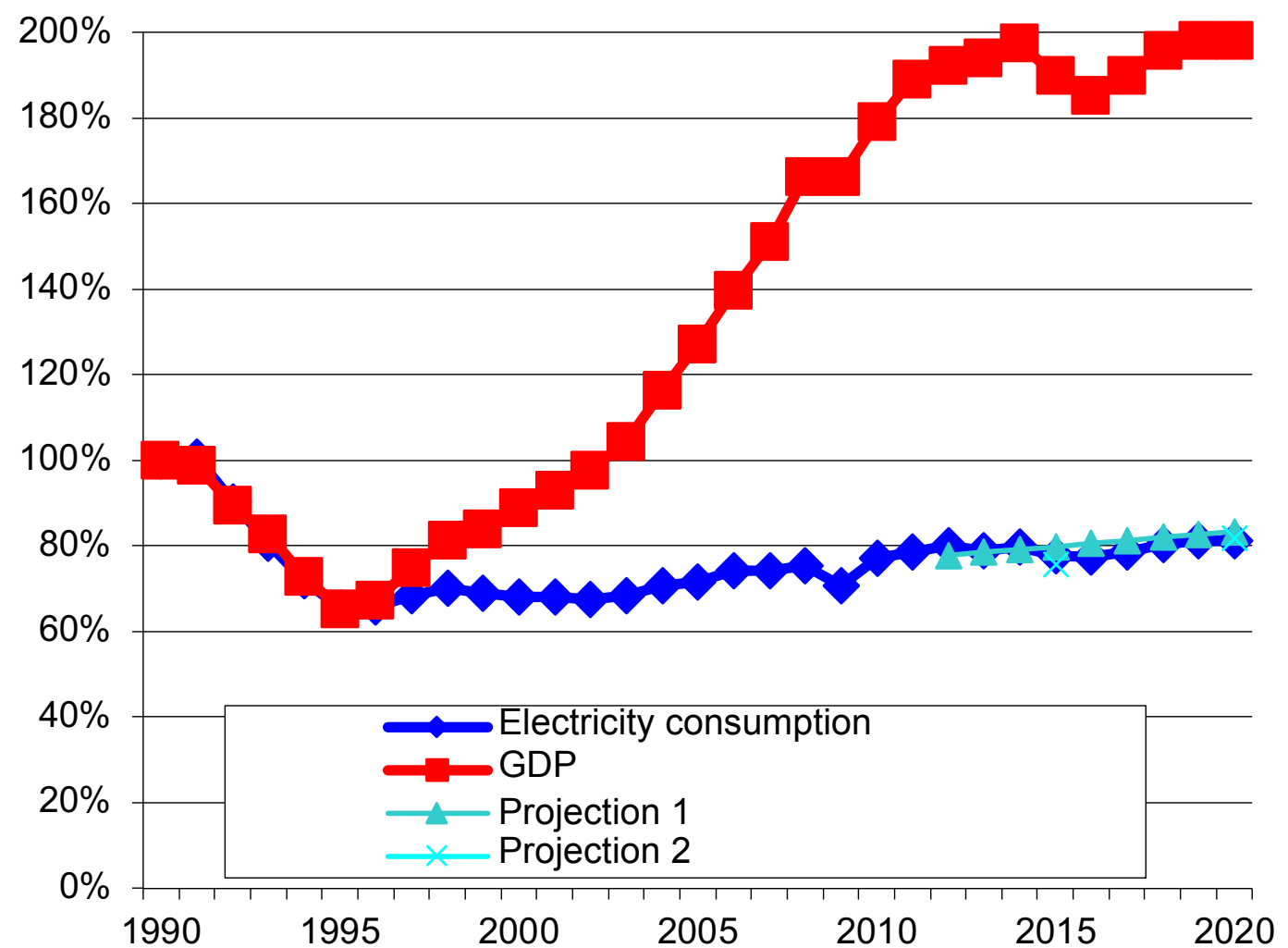

Fig. 1. Historical data and the projection made by B.I. Nigmatulin in 2012 for economic and energy industry performance indicators of the year 2020 .

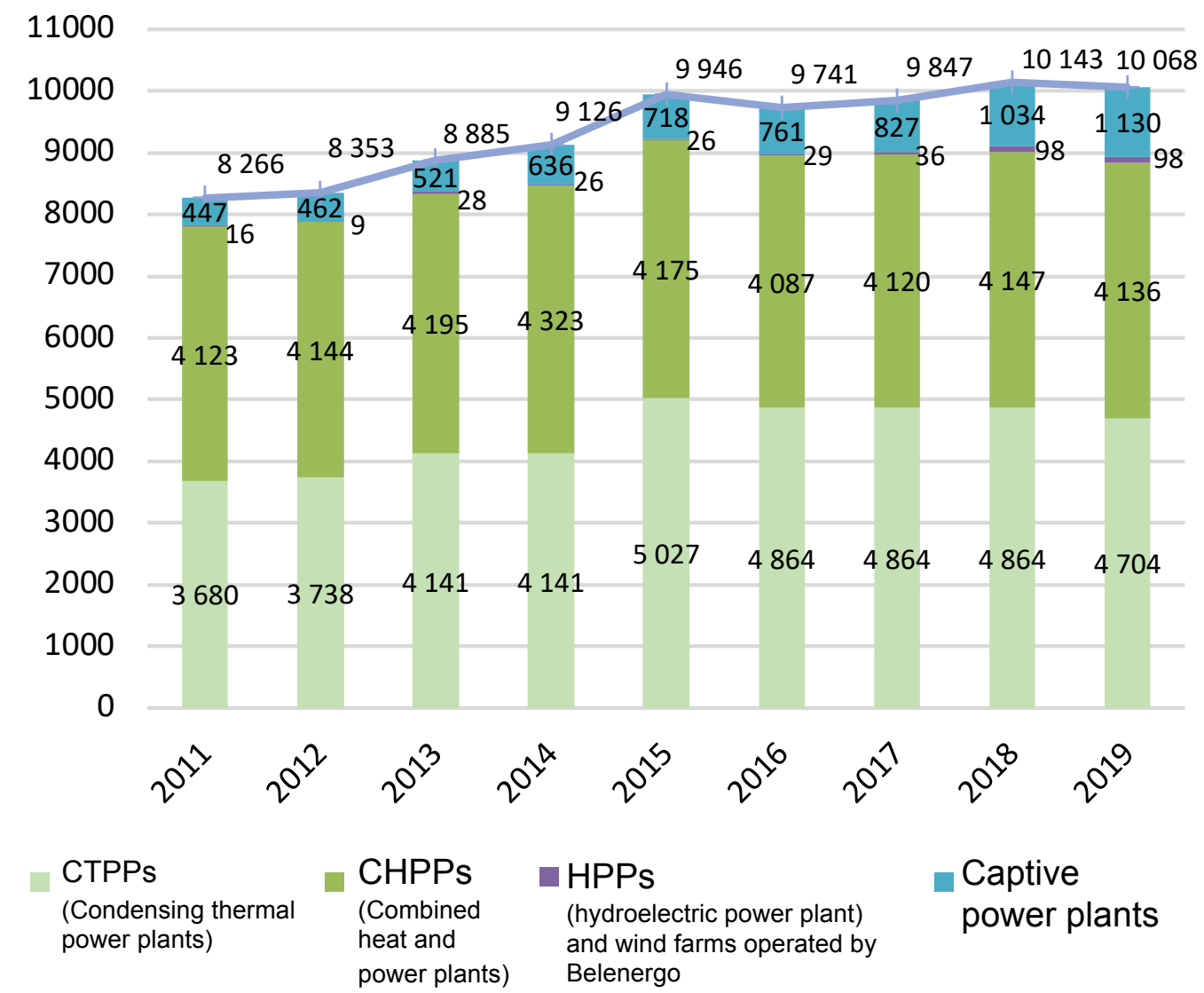

Fig. 2. The mix of installed capacity of generating sources in the power system as of January 1, MW. 


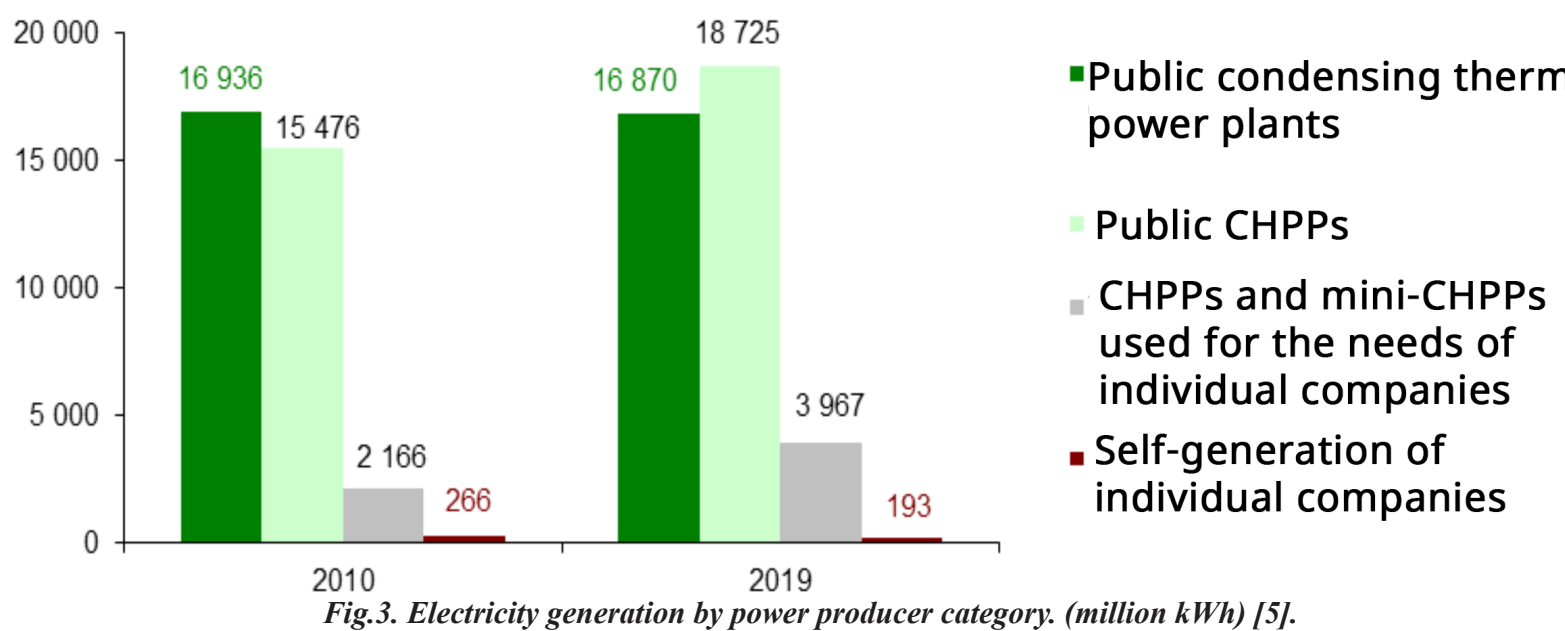

standpoints cover a broad spectrum ranging from those claiming that "the Astravets NPP is completely redundant and will prove a heavy burden on the budgets of countries and consumers" to "All electricity will be sold for the benefit of Russia and Belarus, even if we build another Astravets NPP."

\section{BELARUS DOES NOT NEED THE ASTRAVETS NPP FOR DOMESTIC CONSUMPTION}

1. Belarus' GDP growth potential does not need the Astravets NPP.

The potential for GDP growth and economic growth in Belarus does not need electricity produced by the Astravets NPP. B.I. Nigmatulin showed this back in 2012 based on the correlations of economic and energy development, primarily on an analysis of the elasticity coefficient of electricity consumption in terms of GDP [3].

The installed capacity of Belarus' power system as of January 1, 2019, was 10.068 GW [41], including 4,704 MW of electric power capacity of 3 condensing thermal power plants (CTPPs), 3,856 MW of 14 CHPPs of a capacity over $50 \mathrm{MW}$, and others.

Today, Belarus exports electricity and buys virtually none of it, even without launching the nuclear power plant.

As of now, power generators are hydroelectric and thermal power plants. Belarus needs 33 to 36 billion $\mathrm{kWh}$ of electricity per year, which is fully covered by the capacity of power plants now without the NPP. The two NPP reactors will produce about 18 billion kilowatt-hours of power. This is $\sim 50 \%$ of Belarus' needs, but these needs are already fully covered without the NPP.

Thus, after the NPP launch, there will be a $50 \%$ surplus of power unless other hydroelectric and thermal power plants cease operating.

Calculations by the Republican Unitary Enterprise "BelTEI" [4] (a leading research center of the State Production Association "Belenergo") show a projection of the demand for electricity in the Republic for 2035 under three scenarios: the reference case, reduced demand case, and increased demand case of 40.7 billion $\mathrm{kWh} /$ year, 39.6 billion $\mathrm{kWh} /$ year, and 40.8 billion $\mathrm{kWh} /$ year, respectively.

The minimum load of the Belarusian power system is 25-6 GW. With only two reactors of the Astravets NPP (2,400 MW) and the Lukoml SDPP [State-owned District Power Plant, which is a condensing thermal power plant] $(2,890 \mathrm{MW})$ in operation, it will already be exceeded, and the capacity of the remaining 40 TPPs in Belarus remains unclaimed.

Accordingly, it is necessary to shut down the CTPPs and CHPPs, which is not always an option due to the need for CTPPs to operate in a regulated mode, cogeneration modes, social consequences of shutting down, and others. Alternatively, one should limit their total generation, which markedly reduces their profitability and increases the price.

For example, the Lukoml SDPP operates as a load following plant and the fluctuations in the daily power amount to $1,100 \mathrm{MW}$ [6]. The installed capacity is 2,890 MW. Consequently, the SDPP 1,100/2,890 MW $=40 \%$ of its capacity subject to adjustments, and 1,789.5 MW is the baseload that must be transferred to the NPP. It is assumed that with the commissioning of the Astravets nuclear power plant, only the $300 \mathrm{MW}$ power unit, and CCGT-427 unit will continue operating at the Lukoml SDPP [7]. The Lukoml SDPP will be practically shut down.

Pavel Drozd, Director-General of the State Production Association "Belenergo" said that all CHPPs included in the Association would operate exclusively in the cogeneration mode, which provides mainly heat to consumers [8].

The installed capacity utilization factor (ICUF) of CHPPs and CTPPs, in this case, will be just disastrous, with a disastrous production cost per $\mathrm{kWh}$ and Gcal [6]. Even if we take no account of depreciation costs at 
CTPPs and CHPPs, the decrease in operating costs is not proportional to the output but slower. Accordingly, the effect of reducing the fuel component (uranium vs. gas) is much lower than planned when directly comparing the fuel costs of TPPs and the NPP.

If gas prices are drastically reduced (compared to the expected gas price according to a trend of rising gas prices at the start of construction), the effect is even lower.

Thus, although the Sectoral Program for the Development of the Electric Power Industry (approved by the Decree of the Ministry of Energy of the Republic of Belarus No. 31 of September 4, 2019), does note that the standard service life of a significant part of the generating source equipment will expire by 2020 (which requires their replacement, modernization, or reasonable terms of extension of operation), The total capacity of such equipment is 4,235.7 MW, including that of the Lukoml SDPP - 2,455 MW, Beloozersk (Berezovskaya) SDPP - 330 MW, Novopolotsk CHPP 270 MW, Minsk CHPP-3 - 220 MW, Mozyr CHPP - 205 MW, Bobruis CHPP-2 - 180 MW, Hrodna CHPP-2 - 180 MW, Svetlogorsk CHPP - 155 MW, Mogilevsk CHPP-2 - 150 MW, and 90.7 MW by other CHPPs. The scope of decommissioning of electricity-generating capacities at TPPs will be determined after the NPP reaches its design capacity and successfully integrates into the balance of the power system, the practice suggests that such intentions to replace almost half of the power system capacity, having encountered with infrastructure, economic, social (Lukoml SDPP alone employs more than 1,600 people) and circuit and operating mode issues with respect to regulation and introduction of district heating remain unrealized, and the plants are modernized and extend their service life.

2. Attempts to create an additional consumer for the Astravets NPP power prove ineffective so far

Originally, the Astravets NPP construction project did not involve finding a market for all its output. The search for potential consumers among business entities began in 2016. At that time, consumption was estimated at 1.6 billion $\mathrm{kWh}$ per year ( $\sim 9 \%$ of generation). Per Decree No. 582 of the Council of Ministers of the Republic of Belarus of October 6, 2020 [11], the number of potential projects increased from 148 to 178 over the year, and the projection for electricity consumption was increased by 100 million $\mathrm{kWh}$, from 2.7 to 2.8 billion $\mathrm{kWh}$. Overall, the demand is ensured for 1,191.6 MW of commissioned capacity and 2.8 billion $\mathrm{kWh}$ of the Astravets NPP output. This is half of the total capacity of the system of the two VVER-1200 reactors and $15.6 \%$ of the output.

In 4 years, $6.7 \%$ of demand for the Astravets NPP power was ensured. The contribution of the last year was merely $0.5 \%$.

However, whether even this demand is real depends on the economic situation, which determines the conditions and opportunities of consumers themselves. For example, the Belneftekhim concern's projects are the most energyintensive (construction of a complex for hydrocracking of heavy oil residues, a nitrogen complex, etc.), but their efficiency depends on the state of the market for its products, i.e., petroleum products, fertilizers, and others.

\section{Speaking of electrode boilers}

The heating value of natural gas is $8-10 \mathrm{Gcal} / 1000$ $\mathrm{m}^{3}$ [12]. At $\$ 127$ per $1,000 \mathrm{~m}^{3}$, the cost of a gigacalorie would be $\$ 13-16 /$ Gcal. 1 Gcal corresponds to 1163 $\mathrm{kWh}$. Accordingly, to achieve comparable efficiency of electrode boilers, $1 \mathrm{kWh}$ should cost 1.1-1.4 cents. The expected price of the Astravets NPP electricity is 10-13 cents, which is an order of magnitude higher. Hence, the same applies to the marginal difference in the efficiency of heat generation methods. In electrode boilers, when using electricity from the Astravets NPP, it is an order of magnitude less than in conventional natural gas-fired boiler houses.

Electrode boilers in Belarus are planned to be commissioned for a capacity of 916 MW (eventually up to $1,116 \mathrm{MW}$ ). Commissioning of equipment with a total capacity of $760 \mathrm{MW}$ is envisaged at power plants, including Beloozersk (Berezovskaya) and Lukoml SDPP, CHPPs, and mini-CHPPs. Another $156 \mathrm{MW}$ will be put into operation at boiler houses [13].

In this context, even based on the Astravets NPP electricity price of 10 cents/kWh, the cost of a gigacalorie will be at least $\$ 116$. Retail tariffs for heat, for example, supplied by the republican unitary enterprise "Minskenergo" to legal entities and sole proprietorships, which have been effective since January 1, 2020, are 86-142 Gcal (104 BLR / Gcal, on average), given the 2.1085 USD / BLR exchange rate, [14] or about 50 USD per Gcal, which is more than two times lower than that which can be produced in electrode boilers powered by the Astravets NPP electricity.

Total heat consumption in 2019 was $55(32.9+22.1)$ million Gcal. It would take 64 billion $\mathrm{kWh}$ of electricity to generate heat with electrode boilers. Thus, the entire Astravets NPP excess can be utilized by electrode boilers. At $100 \%$ load of electrode boilers ( 24 hours a day, 365 days a year), their electricity consumption will be $1,160 * 8,760=10.2$ billion $\mathrm{kWh}$ or 8.8 million Gcal.

In this case, at least US\$ $60-65$ million will be lost for every million gigacalories.

\section{Uranium instead of gas - what's the point?}

Assuming the 2020 gas price for Belarus of $\sim 127$ $\$ / 1,000 \mathrm{~m}^{3}$ [15], given the consumption of $\sim 241 \mathrm{goe} / \mathrm{kWh}$ [16], the gas price in the price of electricity is $0.127 \mathrm{\$} / \mathrm{m}^{3}$ : $\left(1,140\right.$ goe $\left./ \mathrm{m}^{3}\right) * 241$ goe $/ \mathrm{kWh}=0.027 \$ / \mathrm{kWh}$.

Accordingly, the gross amount resulting from saving natural gas to generate 18 billion $\mathrm{kWh}$ is $\$ 486$ million per year. At the same time, the loan payments (even under the new, relaxed conditions of $3.3 \%$ per year) are $\sim \$ 700$ 


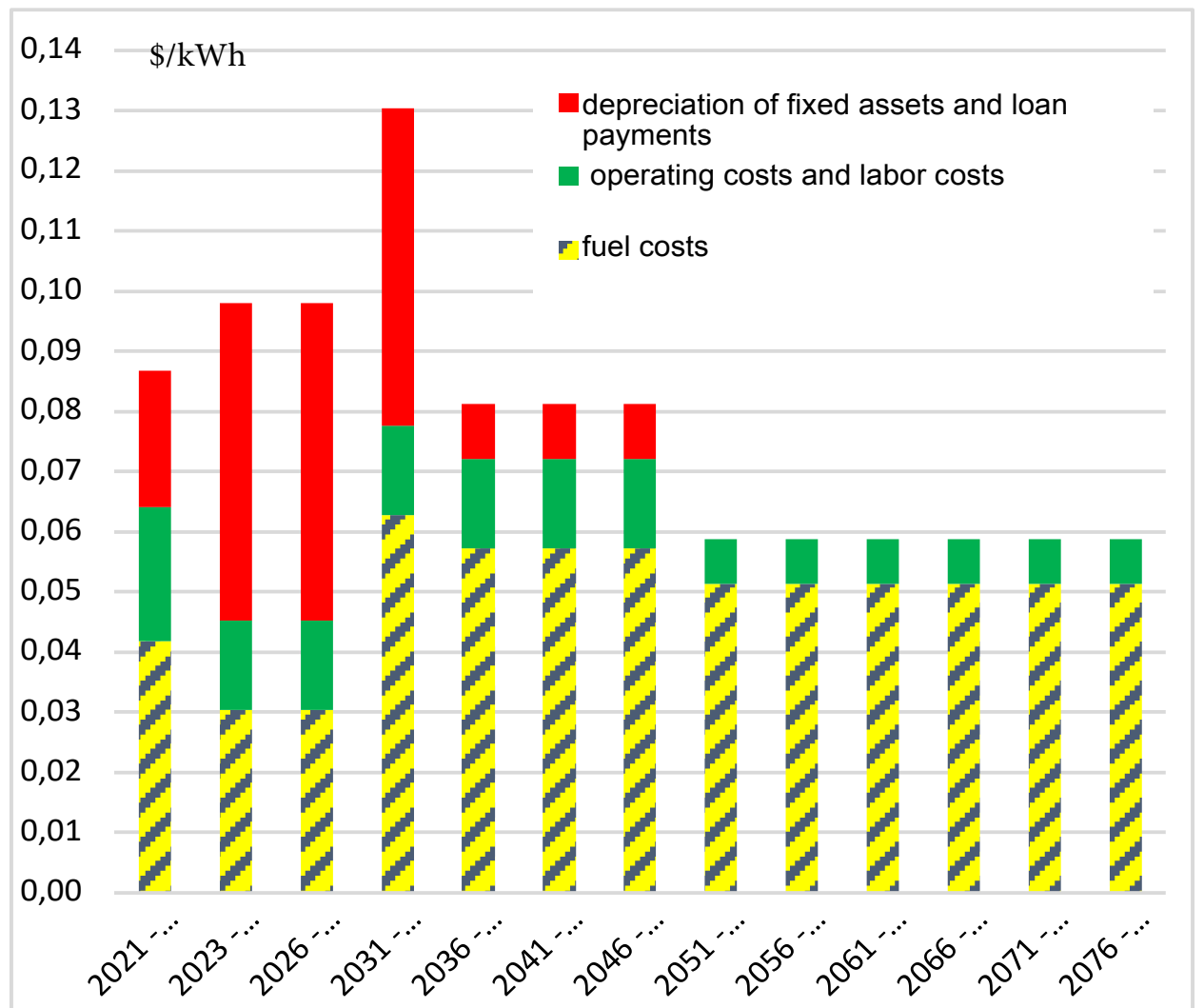

Fig. 4. Components of the cost of electricity generated by the Astravets NPP (aggregated).

million per year [17]. The amount corresponds to the size of the used loan part of US\$ 9-10 billion. Other estimates, based on varying amounts of the loan used, are US\$ 500760 million a year, which is also more than the above value.

That is more than $\$ 200$ million higher than the savings.

However, for the power system and power plants, the price of gas is higher than the price of supply at the state border. For legal entities consuming more than 600 million $\mathrm{m}^{3}$ of gas per year, the gas price is 333.14 Belarusian rubles per $1,000 \mathrm{~m}^{3}$, or $\sim \$ 158 / 1,000 \mathrm{~m}^{3}$ (Given the exchange rate of the Belarusian ruble to the USA dollar of 2.1085:1 ) [18]. Accordingly, the fuel component is $\$ 0.033 / \mathrm{kWh}$, with total savings of $\$ 600$ million per year, which is $\$ 100$ million less than the loan payments.

The above calculations were based on gross savings, i.e., assuming that nuclear fuel costs nothing. However, its price is $\sim 0.019 \$ / \mathrm{kWh}[19]$.

The key motivation behind the construction of the Astravets NPP was the economic effect to be generated by the difference between the prices of nuclear fuel and gas. This difference, given the same sales prices, can yield an additional cash flow to return the capital investment. This effect amounts to $0.027-0.019=0.008 \$ / \mathrm{kWh}$. At 18 billion $\mathrm{kWh}$ per year, this is $\$ 144$ million per year. Thus, the payback period of the $\$ 10$ billion loan principal is 70 years, and given the interest (3.3\% per year) of $\$ 330$ million per year, this means that the loan principal will never be repaid.
III. IS IT POSSIBLE TO SELL THE ASTRAVETS NPP ELECTRIC POWER TO REPAY THE LOAN? THE ELECTRICITY GENERATED BY THE ASTRAVETS NPP IS MORE EXPENSIVE THAN THAT FROM THERMAL POWER PLANTS IN BELARUS. IT IS MORE EXPENSIVE THAN ELECTRICITY IN EUROPE AND MORE EXPENSIVE THAN ELECTRICITY IN RUSSIA

\section{Price calculations for 2018}

The 2018 BelTEI calculations [20] show that the price of electricity generated by the nuclear power plant will be even higher than the price of electricity generated by gasfired thermal power plants. As projected to 2035, the cost of electricity from different types of generating sources, taking into account the increase in fuel prices and the network component, at the start will be:

- 12.57 cents/kWh at gas-fired TPPs; (Hereinafter a cent means US\$ cent. At a gas price of $\$ 152 /$ toe, or $\$ 133 / 1,000 \mathrm{~m}^{3}$ )

- 14.33 cents/kWh at the nuclear power plant.

According to BelTEI's aggregated calculations, the planned cost of electricity output of the Astravets NPP, given the current prices of nuclear fuel and the loan component, is estimated at 10.2 cents $/ \mathrm{kWh}$, including the fuel component of 1.9 cents $/ \mathrm{kWh}$.

Given the terms of the loan for 2018 and the fact that the loan was for 25 years (from 2010 to 2035, repayment of the loan starts with the launch of the NPP in equal installments over 30 months), the loan component is preserved until 2035. On July 14, in Moscow, the 


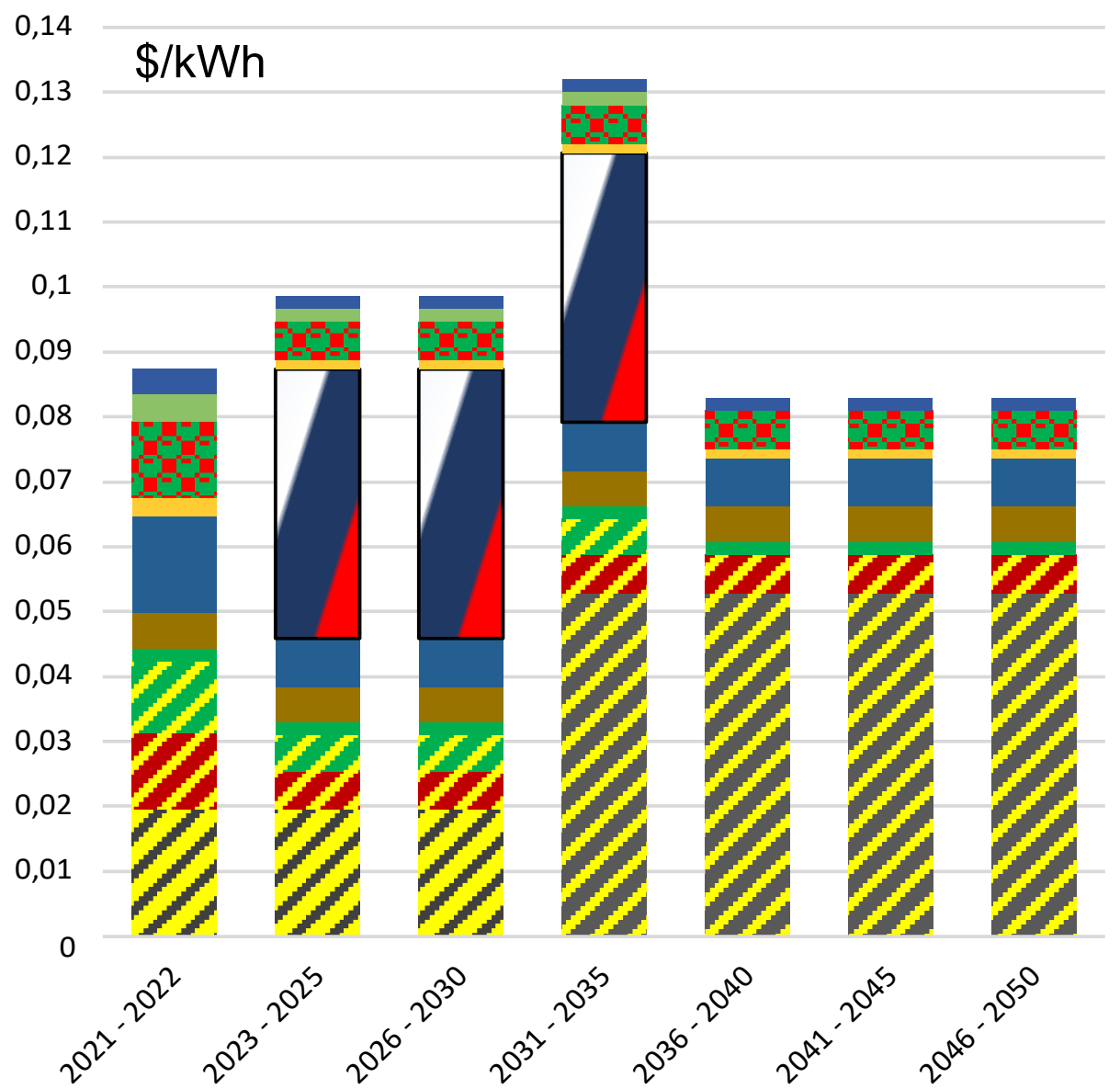

Belarusian investments in electrode boilers, backup and peak power plants, and other grid upgrades

Eximbank loan for power lines

E Belarusian investments in infrastructure

Belarusian investments in the construction of the plant

Russian loan repayments

- decommissioning, decomissioning fund

other expenses

salaries and social payments

allowances for the construction of the storage facility

r. contributions to the fund for radioactive waste and spent nuclear fuel management

F fuel expences (maximum estimated price)

4 fuel expences (minimal low price )

Fig. 5. Components of the cost price of electricity generated by the Astravets NPP (in detail). 
governments of Belarus and Russia signed a protocol on amendments to the agreement on the state export loan for the construction of nuclear power plants by the Belarusian side, dated November 25, 2011. The interest rate on the loan was reduced to $3.3 \%$ per annum, with the rate changed from floating to fixed. With a projected 2.7-fold increase in nuclear fuel prices, the fuel component would increase to 5.13 and the total cost of production to 13.43 cents $/ \mathrm{kWh}$. In the total cost of electricity supplied to consumers, the network component is 0.9 cents $/ \mathrm{kWh}$, and then, with the network component factored in, the total cost at the NPP would be $13.43+0.9=14.33$ cents $/ \mathrm{kWh}$.

\section{Price calculations for 2020}

The updated alternative calculations [21] assume that loan terms changed in mid-2020.

The fuel component for the fuel purchase is assumed to be 1.9 cents per $1 \mathrm{kWh}$, and in general, considering the costs of fuel management and disposal (the calculation of the electricity cost factors in the need to form a budget for spent nuclear fuel management over 30 years and a budget for the construction of storage facility over 15 years.), the fuel component reaches values of 3.0-5.7 cents per $1 \mathrm{kWh}$.

Operating costs cover labor costs, operating costs proper, and additional costs of 1.5-2.2 cents, including plant decommissioning costs in the cost price of electricity generated by the Astravets NPP. With a 30-year decommissioning fund, the cost of decommissioning the nuclear power plant in the cost price of electricity would be 0.75 cents $(0.37$ cents with a 60 -year fund and 1.5 cents with a 15 -year fund.

Capital costs in the cost price of electricity generated by the Astravets NPP, including payments under the loan agreement between Russia and Belarus, the capital components of the cost of infrastructure around the plant, the modernization of the power grid in the cost of electricity generated by the Astravets NPP, etc., are estimated to be 4-4.6 cents until 2050. However, it should be noted that the calculations are not based on the $\$ 10$ billion loan, as outlined in the Agreement, but on $\$ 6.4$ billion [22]. Thus, the actual loan exposure can be much higher.

It is worth noting that it is difficult to calculate the exact amount of the loan debt without accurate information about the cost of the plant and the dates of transferring portions of the loan funds, which is not publicly available today. With the likely underestimation of the cost of the plant, the cost of the loan component increases by 0.4 to 0.6 cents per each underestimated US\$ billion.

\section{The domestic market in Belarus.}

As a whole, from 2023 to 2035 (after the launch of both reactors) the calculations as anchored to a single point (on buses) as well show that the cost price of the Astravets NPP electricity may range from 9.9 to 13.2 cents per $1 \mathrm{kWh}$, depending on fuel prices in the first years of operation of the plant. The cost price of electricity will be $9.7-10.7$ cents on average for the period.
This exceeds the cost price of current gas-fired power generation by 2.5-3.5 times or is comparable to it under the most unfavorable gas prices.

Hence, according to calculations by Belarusian experts, the cost price of electricity in the entire Belarusian energy system will increase 1.8 times, to 7.26 cents per $\mathrm{kWh}$, after the launch of both reactors. [23]

Notably, based on the 2020 tariff decisions in Belarus [24], the price for the end consumer averages 13 cents $/ \mathrm{kWh}$ for business entities (77\%), 9 cents/kWh for households $(23 \%)$, and 11 cents per $1 \mathrm{kWh}$ on average in the country [25], [26], [27].

This price already includes distribution and marketing expenses. Based on these estimates, the Astravets NPP is unprofitable when selling electricity in the domestic market, provided their share in the price for the end consumer is more than $17 \%$. In Germany, this share is over $20 \%$, while in Russia it reaches $50 \%$.

4. Comparison of the price offered by the Astravets NPP with prices in the foreign market (Europe, Russia)

Is it possible to repay the loan by selling the Astravets NPP electricity in the foreign market?

According to the above calculations, the capital costs (assuming 100\% sales and the $\sim 83 \%$ ICUF) in 2023-2035, taking into account the Russian loan, are $\sim 5.3$ cents $/ \mathrm{kWh}$, of which the Russian loan is $\sim 3.7-4.1$ cents $/ \mathrm{kWh}$.

The electricity cost, excluding capital costs, can be attributed to operating costs that include fuel component. Thus, in 2023-2035, the Astravets NPP electricity priced based on operating costs, excluding capital costs (that ensure repayment of loans) and setting up of a decommissioning fund, is $\sim 3.9$ cents per $\mathrm{kWh}$.

Cash flow for return on investment can only come from the difference between the sales price and the operating cost of electricity production if such a difference exists at all.

In this case:

- in the European market (the NordPool exchange), with which both the Baltics and Belarus trade, in 2019, the day-ahead market price for the Baltics was 45.86-46.28 euro/MWh [28], or 5.1-5.2 cents per kWh. At the same time, the price is much lower during the night hours that are relevant for the NPP.

- in the Russian electricity market, in the interconnected power system of Center [29], the day-ahead weighted average index of equilibrium price for selling electricity in the market is 1.284 rubles $/ \mathrm{kW}$, for buying - 1.229 rubles/kWh (November 2019 - November 2020). In terms of the US\$ exchange rate used in the interstate trade, this would be $1,771.85$ cents per $\mathrm{kWh}$.

Thus, the difference (the "margin") that could be spent to reimburse capital costs, including the repayment of the Russian loan, will be no more than $5.1-3.9=1.2$ cents per $\mathrm{kWh}$ when sold in the European market. Given this margin, the corresponding annual flow of funds would not exceed 
\$ 0.2 billion, which is less than the interest payments on the loan alone (!). According to calculations by Belarusian experts, payments on the Russian loan alone under the new terms (3.3\% per annum) are $\sim \$ 0.7$ billion a year, of which 0.49 billion is the principal of the loan, and 0.21 billion is the interest thereon.

However, even with no interest factored in, the volume of the "margin" in the case of sales in the European market corresponds to the term of repayment of the load principal of US\$ 10 billion of over 50 years. This is provided that all electricity is sold to Europe.

Planning sales of the Astravets NPP electricity in the Russian electricity market (in the "day-ahead" segment) should take into account that its price (1.77-1.85 cents per $\mathrm{kWh}$ ) is even lower than the fuel component in the total price of the Astravets NPP electricity, which is 1.9 cents per $\mathrm{kWh}$. Thus, it is impossible to repay the loan by selling the Astravets NPP electricity in the Russian electricity market.

This is impossible, among other things, because there is no possibility to sell capacity, which is a source of income for Russian power plants (and the main one for NPPs).

5. Comparison of the Astravets NPP price with the demand price in the Russian market

Even if we assume that an appropriate mechanism for selling the Astravets NPP power to the Russian market at full cost has been found, it should be evaluated in terms of the end consumer, for example, comparing it to the singlerate tariff in a relevant region of Russia, in particular, in the Smolensk region.

Let us take a typical consumer of 15-500 MWh per month [30] as an example ( Mini-market with a gas station. Round-the-clock cycle plant, etc.). In July 2020, the singlerate tariff for them (at the point of consumption) factored in electricity and capacity from the last resort supplier, the JSC "Atomenergosbyt," and was 2.6-3 rubles/kW. That is, the price in the Russian market was 3.94 .2 cents/ $\mathrm{kWh}$ at an exchange rate of 70.4 rubles/US\$. This price (the ultimate consumer one!) is 1.75 times lower than the average cost of electricity in the Belarusian power system of 7.26 cents per $\mathrm{kWh}$ [31] and corresponds (see above) to the operating costs of the Astravets NPP of 3.9 cents $/ \mathrm{kWh}$, disregarding the recovery of the funds invested in it. The case in question, however, even does not consider the costs of transmitting electricity from the Astravets NPP to the Russian consumer.

Thus, recovery of investment in the Astravets NPP due to the difference in prices (not only for electricity but for the energy supply in general) in Russia and Belarus is also impossible.

6. Comparison of the "worth" of electricity in Belarus and its neighbors in terms of purchasing power parity and energy-GDP ratio

Unfortunately, pricing in the energy industry in a nonmarket environment is highly distorted, and calculation in terms of PPP, which adequately captures the place of the energy industry in the economy, is not accepted in the energy industry of Belarus. This is well-justified and reasonable because, in the absence of the market, pricing is based on the cost of production, which, in turn, is based on the cost of gas. And this fuel component is tied to the US\$ exchange rate.

If pricing were initiated from the side of demand, which is determined by purchasing power, we would have to evaluate and compare the product competitiveness in terms of purchasing power parity. Accordingly, it is necessary to assess and compare the electricity price in Belarus, Russia, and, for example, the Baltic States.

At the same time, comparing the value of Belarusian and Russian electricity for the consumer expressed through the purchasing power parity, we should consider the proportions of the PPP US\$ value and its exchange rate value in both countries. In 2019, it was \$0.4/\$PPP in Russia, \$0.33/\$PPP in Belarus, and \$0.51/\$PPP in Lithuania. Accordingly, the Belarusian electricity introduced into the economy would have cost the consumer $11 / 0.33=33.3$ cents $P P P / k W h$, and the Russian electricity would have cost $4.2 / 0.4=10.5$ cents $\mathrm{PPP} / \mathrm{kWh}$, i.e., more than three times cheaper.

The same ratio holds when comparing Belarus and Lithuania.

This means that it is three times less profitable for Belarus' neighbors to buy electricity from it than to buy their own.

In 2019, consumption in Belarus was 33.185 billion $\mathrm{kWh}$ (Figure 3). The average price for the consumer (see above) is 11 cents per kWh (according to the exchange rate). The nominal GDP of Belarus was (based on the World Bank data) US\$ 63.08 billion. Accordingly, the share of payment for electricity by the economy and population in the GDP was 5.9\%. For comparison, in the United States this figure is $2.1 \%$, in Europe - 3.5\%, and in Russia - 4.1\%. With the commissioning of the Astravets NPP, the disparity will increase.

At the same time, the physical energy-GDP ratios in Russia and Belarus are almost the same - 0.22 and 0.18 $\mathrm{kWh} /$ PPP, respectively. In Belarus, it is slightly lower. Despite this, however, the energy burden on the economy is heavier.

\section{Summary}

All of the above is a fraction of all the possible uses of the Astravets NPP. However, they all indicate that its power is prohibitively expensive and excessive for the country and its neighbors, and its generation, hence, is unprofitable without expanding the market given the specifics of the nuclear power plant. Electricity prices are uncompetitive without special preferences on the part of the government.

However, even the above-mentioned prices for the Astravets NPP electricity were based on its full planned load (the NPP's installed capacity utilization factor is $81-83 \%$ ). Meanwhile, this load depends on how much electricity can be sold in the market, and is it possible to sell it? 


\section{IS IT POSSIBLE TO SELL THE ASTRAVETS NPP ELECTRICITY AT ALL}

\section{Export to the West?}

"Currently, we have many offers and several contracts to export electricity. By the end of 2019, we expect to more than double electricity exports as compared to the last year. I think that with the commissioning of the nuclear power plant, our export potential will increase both technically and economically," said Deputy Head of the Ministry of Energy of Belarus M. Mikhadiuk in his interview to the state agency BELTA on September 18, 2019 [32]. According to him, contracts for exporting Belarusian electricity are signed not only for 2019 but also for the years ahead. "Using the inter-system tie-lines we have with Lithuania, Ukraine, Poland, and Russia, it is possible to export electricity. If there are promising contracts, these ties can be expanded. Therefore, the export will not be zeroed out. I think it will only increase," Mikhadyuk stated.

At the same time, Energy Minister V. Karankevich [33] said: "Last year (2019), power generation in the country as a whole increased by $5 \%$ compared to 2018 . This was made possible by a significant, more than a two-fold increase in power export. The export of electricity amounted to 2.4 billion kWh." Lithuania was the principal buyer, with 1.5 billion $\mathrm{kWh}$ [34].

However, these figures mean that under the production of 39.8 billion $\mathrm{kWh}$ per year (see Fig. 3), export was $2.4 / 39.8=6 \%$, and, accordingly, domestic consumption decreased by $\sim 1 \%$.

Thus, with the already existing excess of electricity exported to the foreign market, possible cessation of export and commissioning of the Astravets NPP make the Belarusian energy system as redundant as possible, consequently, the least efficient possible.

\subsection{The European Union and the Baltic states}

On August 12, 2020, the European Commissioner for Environmental Protection stated that the Baltic States must take the necessary measures to ensure that electricity generated by the Belarusian nuclear power plant (the Astravets NPP) located near the Lithuanian border and 50 $\mathrm{km}$ from Vilnius will not enter the EU energy system. The Seimas (Parliament) of Lithuania declared the Astravets NPP a threat to the national security of the country and in 2017 legislatively banned the purchase and transit of the electricity generated by the NPP through its power grids. The Baltic States confirmed the ban on imports of electricity from the Astravets NPP. At a meeting of the Latvian government on August 25, 2020, the ministers agreed to stop the electricity trade with Belarus if Minsk launches the Astravets NPP [35]. The Baltic States adopted legislative measures to impose the embargo through their elaboration down to specific techniques and technologies [36].

In 2025, the BRELL "energy ring" will cease to operate and the inter-system ties with the Baltic will be severed.

\subsection{Ukraine}

Following Lithuania [37], Ukraine also refused electricity from Belarus [38]. The country also meets its demand with the domestic generation. Kyiv officials say that they see no point in import but want to export electricity. Just like the Baltic States, Ukraine is in the process of synchronization with ENTSO-E. The synchronization is planned to be completed even earlier in 2023. After that, Belarus will have an option to export, even to the EU, but it will have to build an HVDC link with Ukraine, which will cost several hundred million euros. The Ukrainian grid operator Ukrenergo told DW that they are not currently negotiating with the Belarusian side on the HVDC link. "The company does not plan to implement such a project, at least not until the Ukrainian and European power systems are synchronized," he said. In addition to subjective reasons, we should consider the exclusion of Crimea with its demand from the Ukrainian energy system (up to $1 \mathrm{GW}$ ).

\subsection{Poland}

Poland is also not counted as a possible importer. "Based on a brief review of the policies of neighboring states, the conclusion is that there is no guaranteed possibility of exporting electricity. Given the uncertainty of the electricity export/import issues, to ensure energy security, the development of the electric power industry of the Republic of Belarus should be planned omitting the above factor," says the Sectoral Program for the Development of the Electric Power Industry (amended by Decree No. 31 of the Ministry of Energy of the Republic of Belarus of September 4, 2019). Technologically, it also makes no sense because the tie-lines with Poland are weak, and the operation of the power systems is not synchronized.

At the same time, Poland's stance on electricity import from Belarus has been much tougher: "Absolutely no" since 2017 [39]. All the more so because in October 2020, the Polish government passed a decree to update its nuclear power program. The changes involve the construction of two nuclear power plants with six nuclear reactors in total with an overall capacity of $69 \mathrm{GW}$. Nuclear power plants are to be constructed at six-year intervals [40].

The Belorussian Concept for Developing Power Generation Facilities and Power Grids to 2030 also takes this into account [41] - "the economic prerequisites alone do not guarantee the possibility of exporting electricity to Poland, since due to the negative attitude of the European Union to the construction of the Astravets NPP, the Union politically guides Poland towards ruling out the possibility of importing electricity from the Belarusian power system."

\subsection{Summary}

Thus, given the price, political situation, and development plans of countries and power systems, such export destinations as Ukraine, the Baltic States, Poland, and the European Union seem to be absolutely unattainable. 


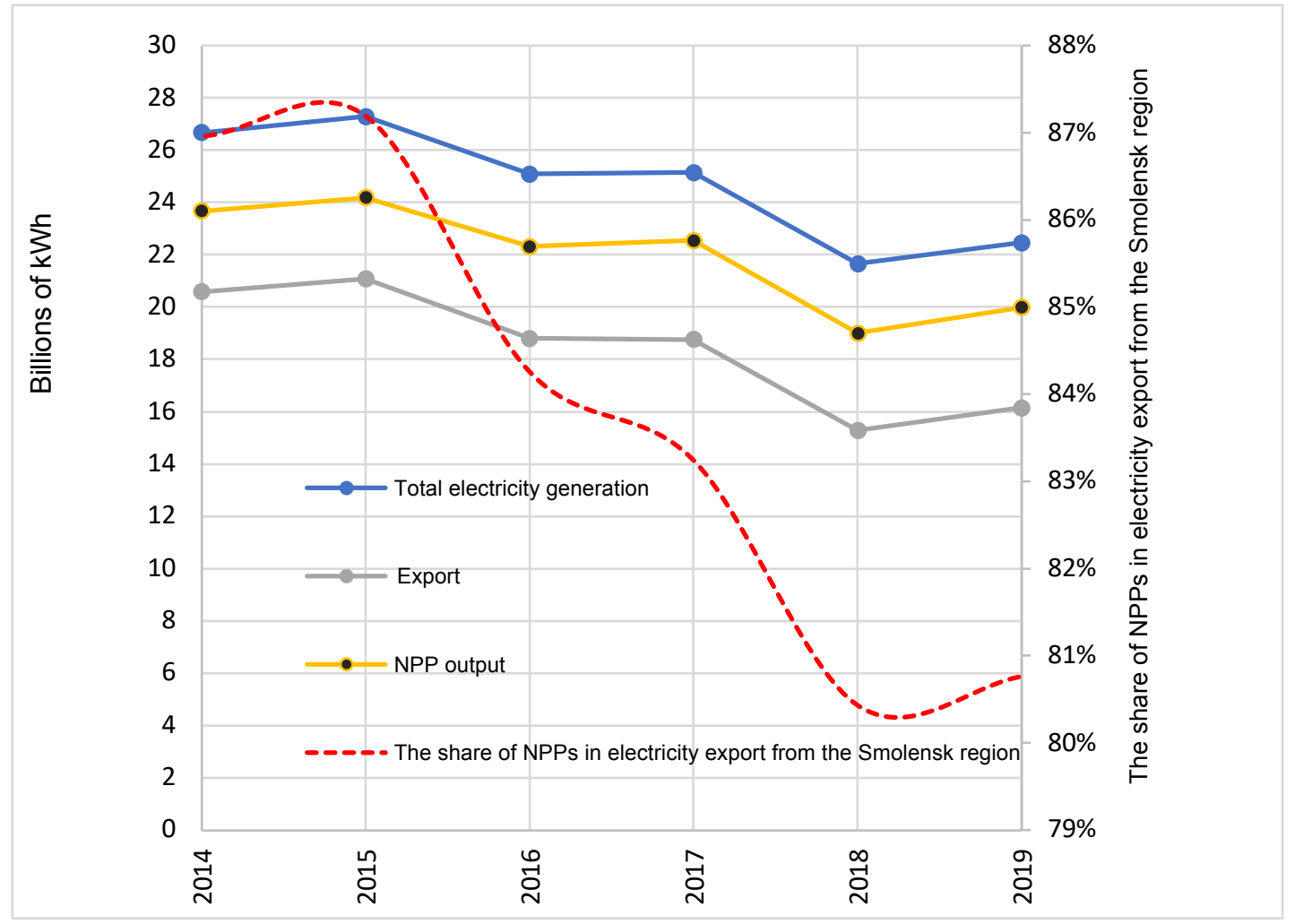

Fig.6. Electricity generation and export in the Smolensk region.

\section{Export to Russia?}

The energy balance of central and western Russia could change dramatically with the introduction of the Astravets NPP. Its capacity is excessive for Belarus, sales to the West are impossible due to, among other reasons, the elimination of the BRELL "energy ring;" the decisions made by the Baltic States, Poland, and Ukraine; and the lack of demand in Europe. Practically, the only way out is to export to Russia in the direction of the Interconnected power system of Center (the Smolensk region). At the same time, Belarusian electricity can take its place in the Russian power market only at the expense of the Russian electricity generation.

The power system of the Smolensk region, as well as the power system of Belarus, are redundant. The installed capacity of power plants exceeds the combined maximum load by a factor of four. The electric power is transmitted to the power systems of Bryansk, Kaluga, Ryazan, and Tver regions. The power balance of the power system is shown in Table 1. As seen, power output from the Smolensk power system has been decreasing almost continuously since 2014. Accordingly, with its domestic power demand (maximum load $<1 \mathrm{GW}$ ), any import from Belarus will be excessive for the Smolensk region; and also for the Tver, Kaluga, Bryansk, and Ryazan regions (for which the Smolensk region may serve as a transit region and where the power flow from the Smolensk power system drops or at least does not increase); and for the Moscow region, where it does not exist.
Table1. Smolensk power system power balance for 2014-2018 [42]

As it follows from the chart (Fig.6):

a. the power export from the Smolensk region is generally declining,

b. the share of exported nuclear power (baseline mode) is declining ahead of schedule,

c. the output of Smolensk NPP is decreasing,

d. the Smolensk NPP is increasingly focused on covering the demand of the region itself, which is small in the first place.

Thus, the electric power of Astravets NPP is not needed in Russia, FOR THE TIME BEING.

This is confirmed in the official documents of the strategic development of the power system of Belarus: [43] "Planning the development of the electric power industry of the Republic of Belarus to 2020 should take into account that, given the lower fuel price for thermal power plants in the Russian Federation, the availability of nuclear power plants in the European Russia, as well as the excess capacity, Russian electricity under market conditions until 2020 will be more competitive compared to the electricity generated in the power system of Belarus, which rules out the possibility of exporting electric power on market terms from the Republic of Belarus to the Russian Federation in the near future.

Thus, with the existing energy market model, the absence of the capacity market segment in the Union's CEM, and non-transparent schemes of paying back the 


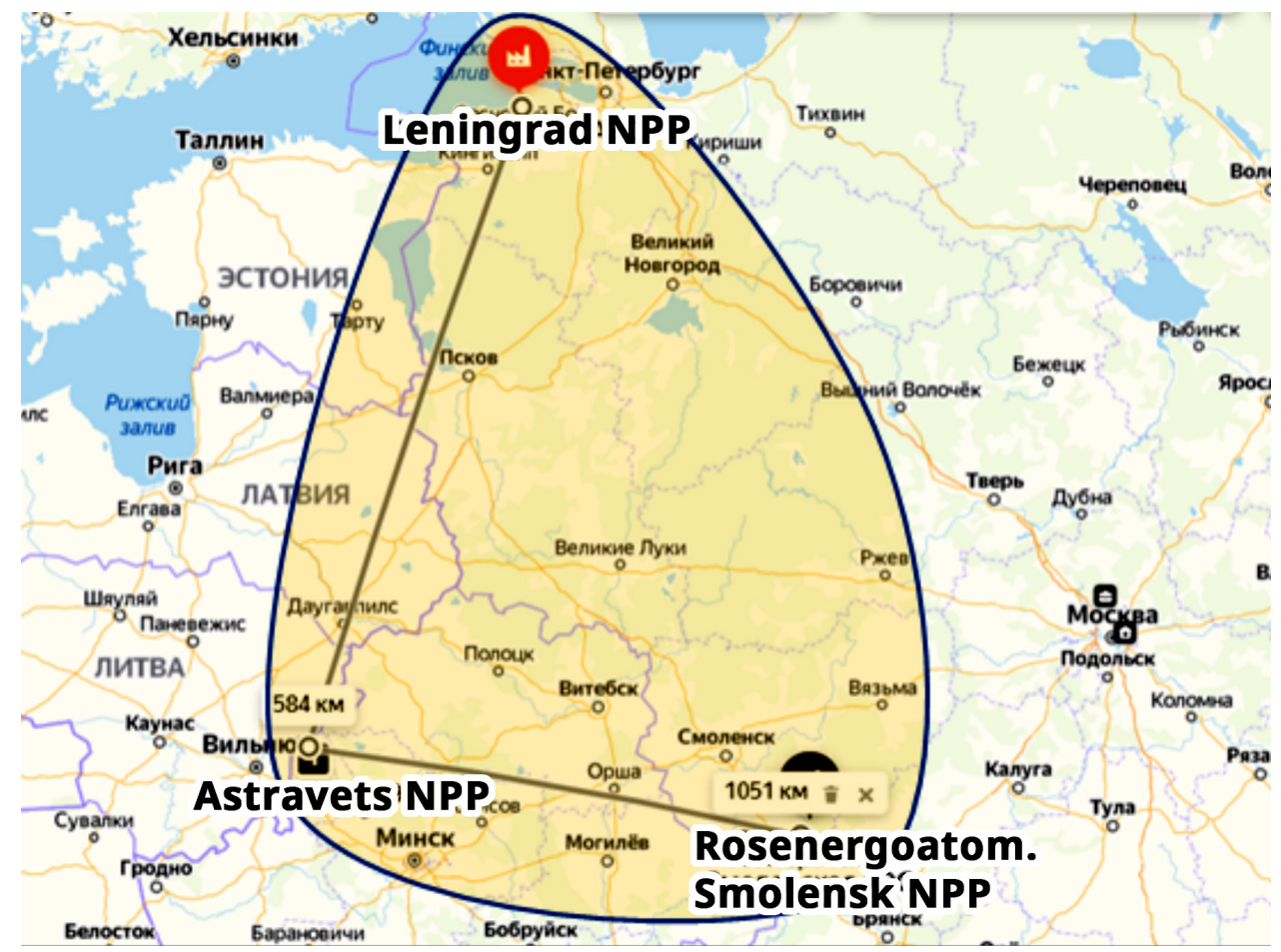

Fig. 7. Configuration of the nuclear power node: IPSs of Center, Northwest, and Belarus.

capital invested in the Astravets NPP, there are political risks of implementing mechanisms of non-market pricing for its electricity ( For example, a reduction in the rate and an increase in the tenor of the loan for the Astravets NPP construction reduces the investment component in the price of electricity in the absence of a capacity market in Belarus and the common electric power market (CEPM) of the EAEU (the Union)), leading to greater competitiveness of the Astravets NPP electricity in the Russian electricity market (the WECM of the Russian Federation), its overstocking, and massive driving out of the Russian generation from the market.

Furthermore, the absence of a consumer, primarily with respect to the baseload part, leads to double risks, first of all, for the Smolensk NPP.

\subsection{Additional risks for Russia}

The problems are aggravated not only by an extremely controversial approach to the plant economics but also by a completely unexpected and full-fledged development of this approach.

In particular, on November 06, 2020, the President of Belarus A.G. Lukashenko stated that the country needs a second nuclear power plant not to depend on oil and gas supplies. "...There will be enough electricity. Our pathetic protesters lament that there's no way to use it but, listen, how come there's no way to use the electricity? We need to build one more such plant to get rid of the dependence on hydrocarbons. This plant is a stroke of luck, a gift," Lukashenko said. [44]

The absence of financial resources in Belarus for construction (it is financed by Russia), on the one hand, and limited sales and, hence, recovery of investment in the Astravets NPP, on the other hand, can make phase two of the Astravets NPP (as well as the project of the existing NPP) a huge and irrecoverable burden on the budget of the Russian Federation.

Moreover, as a "perk", it will be accompanied by the Russian electricity market collapse in the case of uncontrolled subsidization of the investment component of the price.

And, here is "the cherry on top", the Baltic States have already blocked (since November 1, 2020) Russian electricity import to Europe [45], [46] to guarantee the blockade of the Astravets NPP electricity sales to Europe and the Baltic States through Russia as per the substitution arrangement. With the technical inability to "mark" electricity and separate power flow from Belarus, the only solution is to stop the power flows altogether. Similar mechanisms (a ban on import of Russian and Ukrainian nuclear power) were used by the European Union (Eurelectric) to prevent the unification and parallel operation of the EU and CIS power systems in 2002-2007.

\subsection{The Astravets NPP instead of the Smolensk and} Leningrad NPPS

The situation could change radically if, instead of extending the service life (as it already was in 2012), units 1, 2, 3 of RBMK-1000 at the Smolensk NPP, located 475 $\mathrm{km}$ from the Astravets NPP, would be decommissioned in 2027, 2030 and 2035, respectively. That is 3,000 MW. In case of abandoning additional construction of the second reactor of the Astravets NPP, the capacity of nuclear power plants (Smolensk NPP + Astravets NPP) will be 
reduced by $600 \mathrm{GW}$. Otherwise, with the construction of the second reactor of the Astravets NPP, the region will have an additional 1,800 GW of power. The region will be completely dependent on the operation of the Astravets NPP. This, however, raises the questions such as what to do with Desnogorsk with its 27,000 inhabitants, the city where the nuclear power plant maintenance personnel resides? How to regulate? What will it cost to develop the grids?

At the same time, in this region, it is planned by 2025 to decommission four RBMK-1000 units of the Leningrad NPP, which is 600 kilometers from the Astravets NPP. This could lead to a shortage to be met by both the Russian market and the Astravets NPP. The Leningrad NPP, however, has already built next-generation $3+$ power units with VVER-1200 reactors to replace the RBMK-1000.

Therefore, when considering the replacement of the decommissioned capacity at the Smolensk and Leningrad NPPs, assuming that they have not been resolved yet, it should be noted that this is not the case. They have already been resolved in Russia. The relevant documents have already been signed at the government and industry levels.

In June 2020, Rosatom decided [47] to arrange work and appoint those responsible for investment projects to build two units at the Leningrad NPP-2 and two units at the Smolensk NPP-2. Previously, they were included in the General Scheme for Allocation of Electric Power Facilities to 2035 [48], approved by the Russian government.

For the new Leningrad NPP units, the VVER-1200 design was adopted, similar to the first stage of construction of the Leningrad NPP-2. The Smolensk NPP will adopt the VVER-TOI design, similar to the one being built at the Kursk NPP-2. New power units of Smolensk NPP-2 with VVER-TOI reactors of a total capacity of 2,510 megawatts will be built 6 kilometers from the operating nuclear units of the plant. By the end of 2020, it is planned to develop and approve a roadmap for the investment project "Smolensk NPP-2 Nuclear Units 1,2" and open financing for implementation of measures under the roadmap.

Therefore, even if all three RBMK1000 units at the Smolensk NPP are removed from operation, a possible reduction in the capacity of the load center will not exceed $500 \mathrm{MW}$.

2.3. Risk years for the Russian and Belarusian energy sector: 2021-2027

Thus, if we do not take into account the scenario of replacing Russian nuclear capacity with Belarusian capacity (possibly jointly owned and operated by Russian and Belarusian companies), in 2021-2027, the Russian and Belarusian energy industries will compete with each other because of the physical availability of excess capacities and unregulated generation.

This situation will lead to:

- the need to subsidize the Astravets NPP in Belarus, both in terms of paying back the investment and in terms of the cost of creating additional regulated sales,

- the additional burden on consumers, state budgets, and the budgets of energy companies,

- the market risks in Russia in terms of overcapacity and non-market competition, non-transparent pricing, and reduced profitability.

\subsection{Risks of market mechanisms}

There is no capacity market in Belarus. The producer enters the market with a single price, which can factor in both the amount of electricity and capacity volume.

In the Russian market (the Wholesale Electricity and Capacity Market of the Russian Federation, WECM), Russian producers receive payment for capacity within the framework of the capacity market segment: capacity supply agreements (CSA) and competitive capacity outtakes (CCO).

The absence of a capacity market in Belarus and the mismatch between the Belarusian and Russian markets in this segment of the electricity market will lead to the fact that the compensation of the investment component in the cost of electricity generation (which was taken to the capacity market in Russia and financed accordingly), when the Belarusian entity operates in the Russian wholesale electricity market, will prove impossible, as well as it will prove impossible for the Astravets NPP as a nuclear power plant to operate in the WECM of the Russian Federation [49].

From 2025, Belarus, Russia, and other EAEU member states will trade in electricity through the EAEU common electricity market (CEM of the Union). The only commodity to be traded there will be electricity, the price of which may also factor in capacity. In this case, the trade will not take place from the producer to consumer, but at interstate cutsets.

The Astravets NPP, even if owned by Russia, enters the "day-ahead" market of the Russian WECM through the Union's CEM with the full price, including the investment component, while the Russian NPPs do so only with the price for electricity without the capacity charge factored in.

At the same time, the entry of the Astravets NPP into the domestic market and the Union's CEM with different electricity prices could formally lead to discrimination against the consumer. This introduces corresponding risks of non-compliance with the antitrust legislation of the EAEU. On the one hand, Belarusian consumers should enjoy equal rights with Russian consumers, consumers should be in equal conditions, and, on the other hand, external consumers will not be able to pay for the Astravets NPP capacity.

For nuclear power plants, the capacity charge is the main component of the price. The Astravets NPP will not be able to enter the Union's CEM with the full price that would factor in, through this charge, paying back the investment (according to expert estimates, \$50/ 
MWh [50] is for paying back the investment and $\$ 35 /$ $\mathrm{MW}$ is operating and fuel costs; the total is $\$ 85 / \mathrm{MWh}$ ). In Russia, nuclear power plants enter the market with a price-acceptance bid, which may be zero as well, and the main payment is received in the CSA segment, which is not part of the mechanisms of the common market of the EAEU since capacity trading is not available in all countries of the Union, in Belarus, in particular.

For example, if the Astravets NPP enters the Russian market only with an electricity price, all investments become the liability of the Belarusian consumer, and they indirectly subsidize the Russian ones, who pay for the capacity of their NPPs through the internal mechanisms of the Russian WECM and do not pay for the Astravets NPP capacity. If the Astravets NPP enters the Russian market at the full price anyway, its energy is not competitive, since the Astravets NPP does not participate in the CSA of the Russian Federation and will not be able to recover investment costs, having formed, as a generator, the corresponding deductions under the RF CSA. This means that its price in the market has to be higher than in Russia by the value of these costs.

It is also worth taking into account that the Russian rules of the WECM, which ensure the first-priority loading of NPPs in the Russian market [51] (e.g., the Leningrad NPP, Smolensk NPP), do not apply to the entities of electricity markets of other states. In this sense, the Astravets NPP is at a disadvantage in the market if compared to the similar capacity of nuclear power plants, which can be used as a result of the extension of the operating life of the Smolensk NPP and Leningrad NPP.

\section{CONCLUSION. WHAT TO DO?}

If we do not consider the shutdown of the first reactor and the construction of the second reactor at the Astravets NPP, the range of theoretically possible options for solving the sales problem is not broad. In particular, it includes such possible and impossible options as:

Selling all Astravets NPP electricity in the domestic market. This entails the shutting down of half of the thermal power plants in Belarus and the reorientation of the consumer to replace them with the Astravets NPP with the corresponding costs, which are compensated either by an increase in tariffs or from the country's budget. The energy industry will become unprofitable, its burden on the GDP, which is already 3 times higher than that in the USA, 1.7 times higher than in Europe, and 1.4 times higher than in Russia, may increase by at least $20-25 \%$, due to these costs and the loan exposure.

Export. Since export to Europe is unlikely, export means the export to Russia, which involves:

either the complete unification of the electricity and capacity markets or rather, the unconditional and complete implementation of the Russian model in Belarus. Given the decisions adopted by the EAEU member states in 2015-2020, this is impossible.

or granting the Astravets NPP rights, obligations, and preferential advantages equivalent to those of Russian NPPs. Specifically (while the project may be implemented according to the BOO [Build - Own - Operate] model, similar to the Akkuyu NPP in Turkey), the plant should operate in an islanded and extraterritorial mode in terms of dispatch control with the System Operator of the Unified Power System (SO UPS) serving as the basis (the practice of coordination of planning of the Russian and Belarusian power systems can contribute to this). In this case, an appropriate legal regime should be ensured, with cardinal adjustments to the legal framework of Russia and Belarus, allowing for the participation of the Astravets NPP in the capacity market in the WECM of the Russian Federation. In this case, for Rosatom, the Astravets NPP could be a more or less full-fledged replacement for the Smolensk NPP units being decommissioned (in the absence of new construction activities) or the use of a particular structure of contracts for supply to the Russian market through "one window," which makes it possible to bring the supply of two products traded in the Russian market (electricity and capacity) to a single product of the common market of the Union, that is electricity. However, this approach, proposed by Russia and considered in 2016-2018, was rejected by the rest of the EAEU member states. Nevertheless, the possibility of applying the relevant contractual structure is not ruled out, although highly problematic.

It should also be taken into account that if the Smolensk NPP is replaced by the Astravets NPP, even if left with its single reactor (traditionally, the NPP has an even number of reactors), the social issues of Desnogorsk will have to be solved.

All of these scenarios entail a revision of the Master Plan for the Development of the UPS to 2035 and Rosatom's decisions on the construction of two VVERTOI units at the site of the Smolensk NPP.

At the same time, all of these options suggest setting a price, which is more acceptable to the consumer than the existing ones in the Russian market. This problem can be tackled by radically changing the terms of loan repayment, including the alteration of its indemnification forms to Russia, the relaxation of loan conditions (as has already happened) down to complete writing off the loan or the transfer of the loan exposure from the electricity price to the state budget. Even this, however, does not exclude, and, actually, aggravates the consequences for the Russian electricity market with the emergence of a new (and, under these conditions, competitive) producer against the background of its surplus power.

Thus, the only transparent and consistent way out of this situation is to find an additional consumer for the Astravets NPP electricity and capacity. 


\section{REFERENCES}

[1] Decree of the Government of the Russian Federation of 19.06.2020 N 1640-r "On Signing of the Protocol on Amendments to the Agreement between the Government of the Russian Federation and the Government of the Republic of Belarus on Granting State Export Credits to the Government of the Republic of Belarus for the Construction of a Nuclear Power Plant within the Territory of the Republic of Belarus of 25 November 2011". (in Russian)

[2] https://primepress.by/news/kompanii/eksport elektroenergii_posle_zapuska_belaes_tseny_net_ dogovorennosti_est-13540/

[3] Development of the electric power industry in Russia and Belarus: the price of fancies. B.I. Nigmatulin

Chairman of the Expert Council of the Community of Russian Consumers of Electricity. Institute of Energy Research, Moscow, Russia. Talk at the XIV Minsk International Forum on Heat and Mass Transfer. September 13, 2012. (in Russian)

[4] Review of the electricity and heat sector in the Republic of Belarus EEP/CQS/17/01, THE REPUBLICAN UNITARY ENTERPRISE BELTEI) Minsk, 2018 p.81 (in Russian)

[5] https://www.belstat.gov.by/ofitsialnaya-statistika/ realny-sector-ekonomiki/energeticheskayastatistika/graficheskii-material-grafiki-diagrammy/ proizvodstvo-elektricheskoi-energii-po-kategoriyamenergoproizvoditelei/

[6] https://aftershock.news/?q=node/901741

[7] https://www.sb.by/articles/vlastelin-koltsa0901.html

[8] https://minenergo.gov.by/kak-belajes-gotovitsja-kintegracii-v-jenergosistemu/

[9] https://aftershock.news/?q=node/901741

[10] Sectoral program for the development of the electric power industry as amended by Resolution No. 31 of the Ministry of Energy of the Republic of Belarus of September 4, 2019 (in Russian)

[11] https://pravo.by/document/?guid $=12551 \& p 0=\mathrm{C} 2200$ $0582 \& \mathrm{p} 1=1 \& \mathrm{p} 5=0$

[12] GOST 22667-82 (ST SEV 3359-81) (in Russian)

[13] https://www.belta.by/economics/view/elektrokotlymoschnostjju-916-mvt-dlja-integratsii-belaesv-energosistemu-budut-vvedeny-do-kontsagoda-399760-2020/

[14] https://minenergo.gov.by/deyatelnost/ceni_tarifi/

[15] https://www.interfax.ru/business/690139

[16] https://www.energo.by/content/deyatelnostobedineniya/osnovnye-pokazateli/

[17] https://ecohome-ngo.by/wp-content/ uploads/2020/07/Ekodom-otsenka-sebestoimostielektroenergii-BelAES-2020-07-29.pdf

[18] Natural gas prices for legal entities and sole proprietorships in the Republic of Belarus (per the Decree No.8 of the Ministry of Antimonopoly Regulation and Trade of January 30, 2020) (in Russian.)
[19] Review of the Electric and Heat Power Sector / The Republican Unitary Enterprise BELTEI Minsk, 2018. 295. https://drive.google.com/file/d/1SMgNFW2belqb IS_dXt45PKS7oEhFcUj/view?usp=sharing p.124 (in Russian)

[20] Review of the Electric and Heat Power Sector in the Republic of Belarus EEP/CQS/17/01, The Republican Unitary Enterprise BELTEI), Minsk, 2018 p.126 (in Russian)

[21] https://ecohome-ngo.by/wp-content/uploads/2020/07/ Ekodom-otsenka-sebestoimosti-elektroenergiiBelAES-2020-07-29.pdf

[22] https://www.interfax.ru/business/681439

[23] https://ecohome-ngo.by/otsenka-sebestoimostiproizvodstva-elektroenergii-na-ostrovetskoj-aes-i-eyovliyanie-na-energeticheskij-kompleks/

[24] Electricity tariffs for legal entities and sole proprietorships. Registered: Ministry of Antimonopoly Regulation and Trade of the Republic of Belarus. Order No.21 of January 31, 2020 (in Russian)

[25] https://www.energosbyt.by/tariffs.php

[26] https://www.energo.by/content/deyatelnost-obedineniya/ sbytovaya-deyatelnost/rynok-elektricheskoy-i-teplovoyenergii/

[27] https://minenergo.gov.by/wp-content/uploads/jelektro-1. pdf

[28] https://www.nordpoolgroup.com/Market-data1/Dayahead/ Area-Prices/ALL1/Yearly/?view=table

[29] https://www.atsenergo.ru/results/rsv/oes

[30] https://time2save.ru/calculaters/kalulator-cenovihkategoriy

[31] https://ecohome-ngo.by/otsenka-sebestoimostiproizvodstva-elektroenergii-na-ostrovetskoj-aes-i-eyovliyanie-na-energeticheskij-kompleks/

[32] https://primepress.by/news/kompanii/eksport elektroenergii_posle_zapuska_belaes_tseny_net_ dogovorennosti_est-13540/

[33] https://minenergo.gov.by/belarus-v-2019-goduuvelichila-jeksport-jelektrojenergii-bolee-chem-vdva-raza/

[34] https://www.belstat.gov.by/ofitsialnaya-statistika/ realny-sector-ekonomiki/energeticheskaya-statistika/ statisticheskie-izdaniya/index 17875/

[35] https://sputnik.by/politics/20200926/1045761769/ Strany-Baltii-reshili-kak-blokirovat-elektroenergiyus-BelEAS.html

[36] http://tap.mk.gov.lv/lv/mk/tap/?pid=40493750\&mod $\mathrm{e}=\mathrm{mk} \&$ date $=2020-11-03$

[37] http://tap.mk.gov.lv/lv/mk/tap/?pid=40493750\&mod $\mathrm{e}=\mathrm{mk} \&$ date $=2020-11-03$

[38] https://www.belnovosti.by/ekonomika/vsled-zalitvoy-ukraina-otkazalas-ot-elektroenergii-iz-belarusi

[39] https://tass.ru/ekonomika/4846204

[40] https://tass.ru/ekonomika/9757867

[41] The strategic concept of the development of electricity 
generating capacities and power grids to 2030. Decree of the Ministry of Energy of the Republic of Belarus No. 7 of February 25, 2020. (in Russian)

[42] https://rek.admin-smolensk.ru

[43] Sectoral program for the development of the electric power industry for 2016 - 2020, approved by Decree No.8 of the Ministry of Energy of the Republic of Belarus of March 31, 2016 (as amended by Decree No.31 of the Ministry of Energy of the Republic of Belarus of September 4, 2019) (in Russian)

[44] https://www.belta.by/president/view/lukashenkominsk-nado-postepenno-perevodit-naelektrotransport-414380-2020/

[45] https://lt.sputniknews.ru/ economy/20201106/13621500/Litva-budetblokirovat-elektroenergiyu-iz-Belorussii-dovykhoda-iz-BRELL.html

[46] https://naviny.media/new/20201104/1604480526kabmin-latvii-utverdil-otkaz-ot-importa-iz-rossiielektroenergii-s

[47] https://rosatom.ru/journalist/news/v-rossii-budutpostroeny-chetyre-novykh-energobloka-aes/

[48] http://static.government.ru/media/files/ zzvuuhfq2f3OJIK8AzKVsXrGIbW8ENGp.pdf

[49] Para. 4.10, 119, etc. of The Rules of the Wholesale Electricity and Capacity Market of the Russian Federation - PP RF No.1172 of December 27, 2010 (in Russian)

[50] https://ecohome-ngo.by/wp-content/ uploads/2020/07/Ekodom-otsenka-sebestoimostielektroenergii-BelAES-2020-07-29.pdf

[51] Para. 87.1 of The Rules of the Wholesale Electricity and Capacity Market of the Russian Federation - PP RF No.1172 of December 27, 2010 (in Russian)

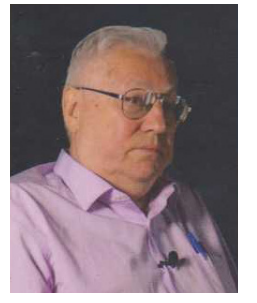

\section{Bulat Nigmatulin}

Dr. habil. in Engineering, Full Professor at the National Research University Moscow Power Engineering Institute.

Graduated from the Faculty of Power Engineering of the Bauman Moscow State Technical University (1967) and the Faculty of Mechanics and Mathematics of the Lomonosov Moscow State University (1969). He defended his doctoral thesis in 1971 and his habilitation thesis in 1983.

Deputy Minister of the Russian Federation for Atomic Energy (19982002).

He currently serves as Director-General at the Institute of Energy Research and Advisor to the Vice President for Marketing and Business Development at the JSC "Rusatom Overseas" of the Rosatom State Nuclear Energy Corporation.

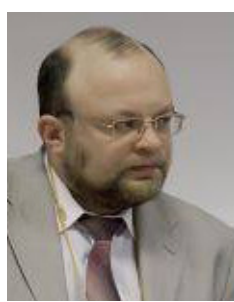

Maxim Saltanov Graduated from Moscow Power Engineering Institute in 1986. Qualification: Thermal Physics Engineer. Nuclear and thermal power plants. Honored Power Engineer of the CIS. Currently is an expert at the Institute of Energy Problems. 